\title{
THE EFFECT OF DIFFERENT PERCENTAGE MIXTURE OF VARIOUS TYPES OF ADMIXTURES USING STONE MATERIALS OF GOLESTAN PROVINCE ON COMPRESSIVE STRENGTH OF PRODUCED CONCRETE
}

\author{
Shabnam Ghasemi Tabrizi \\ A graduate student in civil engineering structures, Gorgan Islamic Azad University, Gorgan, Iran \\ Shabnam.ghasemi@yahoo.com \\ Edris YoosefiRad \\ Department of Civil Engineering, Gorgan Islamic Azad University, Gorgan, Iran \\ Edris.yoosefirad@gmail.com \\ Sasan Iranikhah \\ Department of Civil Engineering, Islamic Azad University of Gorgan, Gorgan, Iran \\ Iranikhah@gorganiau.ac.ir
}

\begin{abstract}
One of the most common methods to improve the mechanical properties and reliability of concrete is replacing part of cement with Pozzolanic admixtures. Pozzolans are silica or silica-aluminum materials reacting with hydration products of cement and they lead to formation of more cement compounds. In this research, 33 mix designs were conducted using Pozzolan micro-silica powder and super plasticizer admixtures by using aggregates of the three cities of Golestan province and compressive strength testing of the samples, and results were examined. Mix designs have been divided in a way that micro-silica powder has been added to all designs and 4 types of super plasticizer admixtures and one cloud plasticizer were used.
\end{abstract}

Key words: mechanical properties, cement, pozzolan, admixtures, super plasticizers

\section{INTRODUCTION}

Concrete has many applications as an important building material in the construction of buildings, bridges, dams. Conducting extensive research designs on various materials comprising concrete and testing various concretes with new materials in recent years have led to the emergence of concretes that in addition to providing resistance, but also it has changed other properties such as durability, softness and efficiency. Concrete in French (Béton) is rooted in Latin word of (Bitume). In the broad meaning, it is defined as any material or compound that is composed of an adhesive material with cementation property. Concrete may be made of different kinds of cement and Pozzolans, furnace slag, added materials, sulfur, admixtures, polymers, fibers, and so on. In addition, different compressors, hydraulic pressures, heat, steam, autoclave, and vacuum might be used in its construction [1]. In other words, concrete is compound material includes various components, including 1 Aggregates in the form of coarse aggregate (gravel) and fine aggregates (sand) that constitute 70 to 80 percent of concrete size.2- cement that binds aggregates in the concrete, directly correlated with concrete strength. 3. Water that plays the role of concrete plasticizer and it improves the efficiency and operation of hydration. Perhaps, less building material can be found that has such diversity, because we can produce concretes with different levels of properties and properties not only by changing the cement, water, and aggregates value, but also by consuming cements and various stone materials. Concrete admixtures are materials other than Portland

Submit Date: 10.05.2016, Acceptance Date: 25.06.2016, DOI NO: 10.7456/1060JSE/012 
cement, aggregates and water that are added to concrete in the form of dust or liquid, as one of the ingredients of the concrete to modify the properties of concrete shortly before or during mixing [2]. In this study, a number of laboratory samples including 3 types of aggregates prepared from three cities of Gorgan, Aliabad, and Bandar Gaz locating in Golestan Province, several kinds of admixtures including plasticizer, cloud plasticizer, micro-silica pozzolan were constructed. After construction of samples, their strength was evaluated and compared.

\section{REVIEW OF LITERATURE}

Concrete is one of the mostly-used building materials. The main feature of concrete is its low cost and availability of its raw materials. Generally, concrete is a product that is constructed by mixture of water, cement, and various aggregates as result of water and cement reaction in special environmental conditions, and it has particular properties. After more than 170 years of Portland cement, today's concrete has been changed dramatically. Availability of its materials, the relatively high durability and need for construction of several mechanisms of concrete structures such as buildings, structures, dams, bridges, tunnels and roads have made that this materials to be widely. The use of this material in certain circumstances has been welcomed by its users for three to four decades. In light of science and technology development, it has been revealed that paying attention merely to strength as a criterion in designing concrete for various environments and applications cannot solve the problems that will be created in the long-term in concrete constructions. The issue of durability in different environments has been taken into consideration in recent years. Observing destructions rooted in chemical and physical factors in concretes in most parts of the world, especially in developing countries, has made that greater attention to be paid on designing concretes with specific properties and higher durability. In this regard, in some countries, guidelines and standards to design concrete with higher performance have been developed, and designers and executives in some developed countries have been obliged to observe these guidelines. In this chapter, we review some studies conducted in the area of adding micro-silica powder and super plasticizers in concrete and impact of each of them on concrete properties. Admixtures are divided into two general categories based on their application:

Mineral admixtures (micro-silica and silica fume) that are mainly materials replacing with part of used and they are one of the ways to reduce cement consumption. The use of micro-silica powder in the mix design increases the compressive strength so that as we increase its rate, its compressive strength is increased. However, excessive use of micro-silica powder reduces the compressive strength that this issue is very important [3]. Chemical admixtures are used mainly at allowed rates (These rates are recommended by manufacturing company) relative to cement materials weight in mix designs.

One of the most widely used chemical admixtures is plasticizer that is reducing water to cement ratio that is the most important factor in improving the mechanical properties of concrete.

Development of chemistry science and the increasing need of building industry for chemical admixtures have led to evolution $n$ industries manufacturer chemical admixtures so that this industry has had the highest development regarding plasticizers and admixtures with higher plasticizer ability have been introduced to market over time, including:

-Melamine-base plasticizer

- Lignosulfonate-based plasticizer

naphthalene-based plasticizer

-_Carboxylate-based plasticizer[4]

studies conducted by other researchers in this regard have shown that plasticizers reduces water, increase initial and final strength of concrete, and increase the efficiency leading to a reduction in concrete

Submit Date: 10.05.2016, Acceptance Date: 25.06.2016, DOI NO: 10.7456/1060JSE/012 
depreciation cost and stiffness. They also increase and the hardness of concrete will be increasing their production of slump making it possible to self-leveling concrete [5,6, and 7]. Additionally, the reason to micro-silica admixture to improve the properties of concrete includes concrete construction with high strength, reduced heat generation, increased wear resistance, increased resistance to sulfates, reduced permeability of concrete, reduced cement alkali reactivity with aggregates, and concrete durability $[8,9$, $10]$.

In a study titled as investigating the impact of aggregate type on concrete compressive strength, Rastad, Yousefzadeh, and Nikoudel used 6 different aggregates and fixed mixture design and same grading curve of constructed concrete to examine the relationship between initial physical properties of aggregates and concrete compressive strength. Finally, they found that stones with higher capacity to absorb the water have greater strength compared to stones with greater initial strength, while their water absorption rate was low [11].

In a study entitled as investigation of stone materials properties of different mines of Gilan province and its impact on mechanical properties of concrete, Ali Sadr Momtazi and Ahmad Amoei assessed and evaluated the properties of 10 sand and gravel mines to find better understanding of stone resources of this province. They described the results achieved on mechanical properties of the concrete, including the investigation of results obtained by tests on compressive strength, tensile strength, flexural strength, and modulus of elasticity, by making cubic, prismatic and cylindrical samples, and they examined the strengths and weaknesses of these materials [12].

Materials and method of study

To conduct this study, following materials were used:

1. Micro-silica powder

2. MS-MIX concrete super plasticizer

3. LS-MIX concrete super plasticizer

4. PX-MI concrete super plasticizer

5. NS-MIX concrete super plasticizer

6. PX-MIX cloud plasticizer

7. Types of aggregates produced from mines in Bandar Gaz, Gorgan and Aliabad with different geometric shapes and aggregation

\section{Cement}

9. Water

Since environmental, human and instrumental conditions and factors are effective in laboratory studies, it is necessary that experiments to be conducted with careful planning. In this study, 33 mix designs including $30 \mathrm{mix}$ designs with admixtures (micro-silica powder, four types of plasticizers and 1 concrete cloud plasticizer) at a fixed grade and 3 mix designs of ordinary concrete were designed and constructed for controlling. In construction of the mentioned concretes, ordinary Portland cement type 2 and the admixture called micro-silica powder were used. Four types of plasticizers and one cloud plasticizer and broken and mineral aggregates prepared from three cities of Golestan province (Aliabad, Gorgan, Bandar Gaz) with the largest aggregate size of 1 inch were used. Compressive strength of produced samples was evaluated. Tables 1 to 3 show different modes of mix design. 
The Turkish Online Journal of Design, Art and Communication - TOJDAC July 2016 Special Edition

Table 1- details of Aliabad Katul design

\begin{tabular}{|c|c|c|c|c|c|c|c|c|c|c|c|}
\hline $\begin{array}{l}\text { Name of } \\
\text { design }\end{array}$ & $\begin{array}{l}\text { Water } \\
\text { to } \\
\text { cement } \\
\text { ratio } \\
(\mathrm{w} / \mathrm{c})\end{array}$ & $\begin{array}{r}\text { Cement } \\
\mathrm{kg} / \mathrm{m}^{3}\end{array}$ & $\begin{array}{l}\text { Oval } \\
\mathrm{kg} / \mathrm{m}^{3}\end{array}$ & $\begin{array}{c}\mathrm{Pea} \\
\mathrm{kg} / \mathrm{m}^{3}\end{array}$ & $\begin{array}{l}\text { sand } \\
\mathrm{kg} / \mathrm{m}^{3}\end{array}$ & $\begin{array}{c}\text { Micro- } \\
\text { silica } \\
\text { powder } \\
\mathrm{kg} / \mathrm{m}^{3}\end{array}$ & $\begin{array}{c}\text { super } \\
\text { plasticizer } \\
\mathrm{NS} \\
\mathrm{kg} / \mathrm{m}^{3}\end{array}$ & $\begin{array}{c}\text { super } \\
\text { plasticizer } \\
\text { PX } \\
\mathrm{kg} / \mathrm{m}^{3}\end{array}$ & $\begin{array}{c}\text { super } \\
\text { plasticizer } \\
\text { LS } \\
\mathrm{kg} / \mathrm{m}^{3}\end{array}$ & $\begin{array}{c}\text { super } \\
\text { plasticizer } \\
\text { MS } \\
\mathrm{kg} / \mathrm{m}^{3}\end{array}$ & $\begin{array}{c}\text { super } \\
\text { plasticizer } \\
\text { PX } \\
\\
\mathrm{kg} / \mathrm{m}^{3}\end{array}$ \\
\hline 1 & $4 / 0$ & 350 & 456 & 456 & 913 & & & & & & \\
\hline 2 & $4 / 0$ & 350 & 456 & 456 & 913 & 25 & $5 / 3$ & & & & \\
\hline 3 & $39 / 0$ & 350 & 456 & 456 & 913 & 25 & $2 / 4$ & & & & \\
\hline 4 & $4 / 0$ & 350 & 456 & 456 & 913 & 25 & & $1 / 2$ & & & \\
\hline 5 & $4 / 0$ & 350 & 456 & 456 & 913 & 25 & & $45 / 2$ & & & \\
\hline 6 & $39 / 0$ & 350 & 456 & 456 & 913 & 25 & & & $5 / 3$ & & \\
\hline 7 & $4 / 0$ & 350 & 456 & 456 & 913 & 25 & & & $2 / 4$ & & \\
\hline 8 & $4 / 0$ & 350 & 456 & 456 & 913 & 25 & & & & $15 / 3$ & \\
\hline 9 & $39 / 0$ & 350 & 456 & 456 & 913 & 25 & & & & $85 / 3$ & \\
\hline 10 & $38 / 0$ & 350 & 456 & 456 & 913 & 25 & & & & & $22 / 1$ \\
\hline 11 & $39 / 0$ & 350 & 456 & 456 & 913 & 25 & & & & & $57 / 1$ \\
\hline
\end{tabular}

Table 2- details of Gorgan design

\begin{tabular}{|c|c|c|c|c|c|c|c|c|c|c|c|}
\hline $\begin{array}{l}\text { Name } \\
\text { of } \\
\text { design }\end{array}$ & $\begin{array}{l}\text { Water } \\
\text { to } \\
\text { cement } \\
\text { ratio } \\
(\mathrm{w} / \mathrm{c})\end{array}$ & $\begin{array}{c}\text { Cement } \\
\mathrm{kg} / \mathrm{m}^{3}\end{array}$ & $\begin{array}{l}\text { Oval } \\
\mathrm{kg} / \mathrm{m}^{3}\end{array}$ & $\begin{array}{c}\text { Pea } \\
\mathrm{kg} / \mathrm{m}^{3}\end{array}$ & $\begin{array}{l}\text { sand } \\
\mathrm{kg} / \mathrm{m}^{3}\end{array}$ & $\begin{array}{l}\text { Micro-silica } \\
\text { powder } \\
\mathrm{kg} / \mathrm{m}^{3}\end{array}$ & $\begin{array}{c}\begin{array}{c}\text { super } \\
\text { plasticizer }\end{array} \\
\mathrm{NS} \\
\mathrm{kg} / \mathrm{m}^{3}\end{array}$ & $\begin{array}{c}\text { super } \\
\text { plasticizer } \\
\text { PX } \\
\\
\mathrm{kg} / \mathrm{m}^{3}\end{array}$ & $\begin{array}{c}\text { super } \\
\text { plasticizer } \\
\text { LS } \\
\mathrm{kg} / \mathrm{m}^{3}\end{array}$ & $\begin{array}{c}\text { super } \\
\text { plasticizer } \\
\text { MS } \\
\mathrm{kg} / \mathrm{m}^{3}\end{array}$ & $\begin{array}{c}\text { super } \\
\text { plasticizer } \\
\text { PX } \\
\mathrm{kg} / \mathrm{m}^{3}\end{array}$ \\
\hline 1 & $45 / 0$ & 350 & 456 & 456 & 913 & & & & & & \\
\hline 2 & $43 / 0$ & 350 & 456 & 456 & 913 & 25 & $5 / 3$ & & & & \\
\hline 3 & $43 / 0$ & 350 & 456 & 456 & 913 & 25 & $2 / 4$ & & & & \\
\hline 4 & $41 / 0$ & 350 & 456 & 456 & 913 & 25 & & $1 / 2$ & & & \\
\hline 5 & $39 / 0$ & 350 & 456 & 456 & 913 & 25 & & $45 / 2$ & & & \\
\hline 6 & $44 / 0$ & 350 & 456 & 456 & 913 & 25 & & & $5 / 3$ & & \\
\hline 7 & $44 / 0$ & 350 & 456 & 456 & 913 & 25 & & & $2 / 4$ & & \\
\hline 8 & $35 / 0$ & 350 & 456 & 456 & 913 & 25 & & & & $15 / 3$ & \\
\hline 9 & $37 / 0$ & 350 & 456 & 456 & 913 & 25 & & & & $85 / 3$ & \\
\hline 10 & $37 / 0$ & 350 & 456 & 456 & 913 & 25 & & & & & $22 / 1$ \\
\hline 11 & $38 / 0$ & 350 & 456 & 456 & 913 & 25 & & & & & $57 / 1$ \\
\hline
\end{tabular}

Submit Date: 10.05.2016, Acceptance Date: 25.06.2016, DOI NO: 10.7456/1060JSE/012 Copyright (C) The Turkish Online Journal of Design, Art and Communication 
The Turkish Online Journal of Design, Art and Communication - TOJDAC July 2016 Special Edition

Table 3- details of Bandar Gaz design

\begin{tabular}{|c|c|c|c|c|c|c|c|c|c|c|c|}
\hline $\begin{array}{l}\text { Name } \\
\text { of } \\
\text { design }\end{array}$ & $\begin{array}{l}\text { Water } \\
\text { to } \\
\text { cement } \\
\text { ratio } \\
(\mathrm{w} / \mathrm{c})\end{array}$ & $\begin{array}{c}\text { Cement } \\
\mathrm{kg} / \mathrm{m}^{3}\end{array}$ & $\begin{array}{l}\text { Oval } \\
\mathrm{kg} / \mathrm{m}^{3}\end{array}$ & $\underset{\mathrm{kg} / \mathrm{m}^{3}}{\mathrm{Pea}}$ & $\begin{array}{l}\text { sand } \\
\mathrm{kg} / \mathrm{m}^{3}\end{array}$ & $\begin{array}{c}\text { Micro- } \\
\text { silica } \\
\text { powder } \\
\mathrm{kg} / \mathrm{m}^{3}\end{array}$ & $\begin{array}{c}\begin{array}{c}\text { super } \\
\text { plasticizer }\end{array} \\
\mathrm{NS} \\
\mathrm{kg} / \mathrm{m}^{3}\end{array}$ & $\begin{array}{c}\text { super } \\
\text { plasticizer } \\
\text { PX } \\
\\
\mathrm{kg} / \mathrm{m}^{3}\end{array}$ & $\begin{array}{c}\text { super } \\
\text { plasticizer } \\
\text { LS } \\
\\
\mathrm{kg} / \mathrm{m}^{3}\end{array}$ & $\begin{array}{c}\text { super } \\
\text { plasticizer } \\
\text { MS } \\
\\
\mathrm{kg} / \mathrm{m}^{3}\end{array}$ & $\begin{array}{c}\text { super } \\
\text { plasticizer } \\
\text { PX } \\
\mathrm{kg} / \mathrm{m}^{3}\end{array}$ \\
\hline 1 & $41 / 0$ & 350 & 456 & 456 & 913 & & & & & & \\
\hline 2 & $4 / 0$ & 350 & 456 & 456 & 913 & 25 & $5 / 3$ & & & & \\
\hline 3 & $4 / 0$ & 350 & 456 & 456 & 913 & 25 & $2 / 4$ & & & & \\
\hline 4 & $39 / 0$ & 350 & 456 & 456 & 913 & 25 & & $1 / 2$ & & & \\
\hline 5 & $4 / 0$ & 350 & 456 & 456 & 913 & 25 & & $45 / 2$ & & & \\
\hline 6 & $41 / 0$ & 350 & 456 & 456 & 913 & 25 & & & $5 / 3$ & & \\
\hline 7 & $41 / 0$ & 350 & 456 & 456 & 913 & 25 & & & $2 / 4$ & & \\
\hline 8 & $40 / 0$ & 350 & 456 & 456 & 913 & 25 & & & & $15 / 3$ & \\
\hline 9 & $39 / 0$ & 350 & 456 & 456 & 913 & 25 & & & & $85 / 3$ & \\
\hline 10 & $37 / 0$ & 350 & 456 & 456 & 913 & 25 & & & & & $22 / 1$ \\
\hline 11 & $35 / 0$ & 350 & 456 & 456 & 913 & 25 & & & & & $57 / 1$ \\
\hline
\end{tabular}

This study consisted of 33 mix designs and each mix design and four test pieces were modeled for each of mix designs. Finally, 132 test pieces were obtained. Dimensions of all test pieces were $15 \times 15 \times 15 \mathrm{~cm}$ in accordance with the Iran Concrete Regulations. The number of the test pieces was calculated 7-day and 28-day for compressive strength tests. In each test, two test pieces were tested and its mean was considered as result of any test.

RESULTS AND DISCUSSION

COMPRESSIVE STRENGTH TESTS RESULTS

Table 4- compressive strength tests results with grade of $350 \mathrm{~kg} / \mathrm{m}^{3}$ in Aliabad Katul city

\begin{tabular}{|c|c|c|c|c|c|}
\hline \multicolumn{6}{|c|}{ Result of determining concrete compressive test } \\
\hline \multicolumn{3}{|c|}{ Cement type:type 2 shahrood } & \multicolumn{3}{|c|}{ Sample type: cubic } \\
\hline \multicolumn{2}{|c|}{ Cubic samples strength } & \multirow{3}{*}{$\begin{array}{l}\text { Special } \\
\text { weight }\end{array}$} & \multirow[t]{3}{*}{ slump } & \multirow{3}{*}{$\begin{array}{l}\text { Cement } \\
\text { grade }\end{array}$} & \multirow[t]{3}{*}{ Sample number } \\
\hline 28-day & & & & & \\
\hline & 7-day & & & & \\
\hline 384 & 301 & 2.41 & 8 & 350 & 1 \\
\hline
\end{tabular}

Submit Date: 10.05.2016, Acceptance Date: 25.06.2016, DOI NO: 10.7456/1060JSE/012 
The Turkish Online Journal of Design, Art and Communication - TOJDAC July 2016 Special Edition

\begin{tabular}{|c|c|c|c|c|c|}
\hline 488 & 412 & 2.44 & 10 & 350 & 2 \\
\hline 525 & 443 & 2.43 & 10 & 350 & 3 \\
\hline 459 & 430 & 2.38 & 11 & 350 & 4 \\
\hline 482 & 437 & 2.41 & 11 & 350 & 5 \\
\hline 490 & 428 & 2.41 & 12 & 350 & 6 \\
\hline 482 & 421 & 2.35 & 12 & 350 & 7 \\
\hline 500 & 447 & 2.42 & 13 & 350 & 8 \\
\hline 488 & 454 & 2.39 & 13 & 350 & 9 \\
\hline 559 & 479 & 2.47 & 9 & 350 & 10 \\
\hline 565 & 490 & 2.49 & 9 & 350 & 11 \\
\hline
\end{tabular}

As it is seen in Table 4 related to results of compressive strength of 11 designs in Aliabad

city, the highest 7-day and 28-day strength related to design 11 that included PX-MIX clod plasticizer that is based on polycarboxylate ether.

Table 5. Concrete compressive strength test results with grade $350 \mathrm{~kg} / \mathrm{m} 3$ in Gorgan city

\begin{tabular}{|c|c|c|c|c|c|}
\hline \multicolumn{6}{|c|}{ Result of determining concrete compressive test } \\
\hline \multicolumn{3}{|c|}{ Cement type:type 2 shahrood } & \multicolumn{3}{|c|}{ Sample type: cubic } \\
\hline \multicolumn{2}{|c|}{ Cubic samples strength } & \multirow{3}{*}{$\begin{array}{l}\text { Special } \\
\text { weight }\end{array}$} & \multirow[t]{3}{*}{ slump } & \multirow{3}{*}{$\begin{array}{l}\text { Cement } \\
\text { grade }\end{array}$} & \multirow[t]{3}{*}{ Sample number } \\
\hline 28-day & & & & & \\
\hline & 7-day & & & & \\
\hline 375 & 288 & 2.46 & 7 & 350 & 1 \\
\hline 476 & 375 & 2.41 & 10 & 350 & 2 \\
\hline 451 & 396 & 2.47 & 11 & 350 & 3 \\
\hline 493 & 439 & 2.43 & 11 & 350 & 4 \\
\hline 536 & 460 & 2.44 & 11 & 350 & 5 \\
\hline 529 & 445 & 2.44 & 12 & 350 & 6 \\
\hline 508 & 435 & 2.42 & 12 & 350 & 7 \\
\hline 510 & 439 & 2.47 & 12 & 350 & 8 \\
\hline 512 & 449 & 2.49 & 13 & 350 & 9 \\
\hline 529 & 460 & 2.48 & 8 & 350 & 10 \\
\hline 539 & 467 & 2.44 & 9 & 350 & 11 \\
\hline
\end{tabular}

Submit Date: 10.05.2016, Acceptance Date: 25.06.2016, DOI NO: 10.7456/1060JSE/012 Copyright $(\subset)$ The Turkish Online Journal of Design, Art and Communication 
As it is seen in Table 5 related to results of compressive strength of 11 designs in Gorgan city, the highest 7-day and 28-day strength related to design 11 that included PX-MIX clod plasticizer that is based on polycarboxylate ether.

Table 6. Concrete compressive strength test results with grade $350 \mathrm{~kg} / \mathrm{m} 3$ in Bandar Gaz city

\begin{tabular}{|c|c|c|c|c|c|}
\hline \multicolumn{6}{|c|}{ Result of determining concrete compressive test } \\
\hline \multicolumn{3}{|c|}{ Cement type:type 2 shahrood } & \multicolumn{3}{|c|}{ Sample type: cubic } \\
\hline \multicolumn{2}{|c|}{ Cubic samples strength } & \multirow{3}{*}{$\begin{array}{l}\text { Special } \\
\text { weight }\end{array}$} & \multirow[t]{3}{*}{ slump } & \multirow{3}{*}{$\begin{array}{l}\text { Cemen } \\
\text { t grade }\end{array}$} & \multirow{3}{*}{$\begin{array}{l}\text { Sample } \\
\text { number }\end{array}$} \\
\hline 28-day & & & & & \\
\hline & 7-day & & & & \\
\hline 352 & 253 & 2.41 & 8 & 350 & 1 \\
\hline 417 & 321 & 2.39 & 10 & 350 & 2 \\
\hline 438 & 361 & 2.43 & 10 & 350 & 3 \\
\hline 472 & 389 & 2.41 & 11 & 350 & 4 \\
\hline 508 & 405 & 2.41 & 11 & 350 & 5 \\
\hline 436 & 334 & 2.42 & 12 & 350 & 6 \\
\hline 479 & 373 & 2.41 & 12 & 350 & 7 \\
\hline 500 & 406 & 2.42 & 12 & 350 & 8 \\
\hline 510 & 399 & 2.4 & 12 & 350 & 9 \\
\hline 532 & 430 & 2.43 & 8 & 350 & 10 \\
\hline 547 & 439 & 2.42 & 9 & 350 & 11 \\
\hline
\end{tabular}

As it is seen in Table 6 related to results of compressive strength of 11 designs in Bandar Gaz city, the highest 7-day and 28-day strength related to design 11 that included PX-MIX clod plasticizer that is based on polycarboxylate ether.

\section{CONCRETE WITH DIFFERENT CEMENT GRADES OF ADMIXTURES (ORDINARY CONCRETE)}

According to the diagram below, you can see that the highest strength was in the state without admixture related to Aliabad city, followed by Gorgan and Bandar Gaz, respectively. 


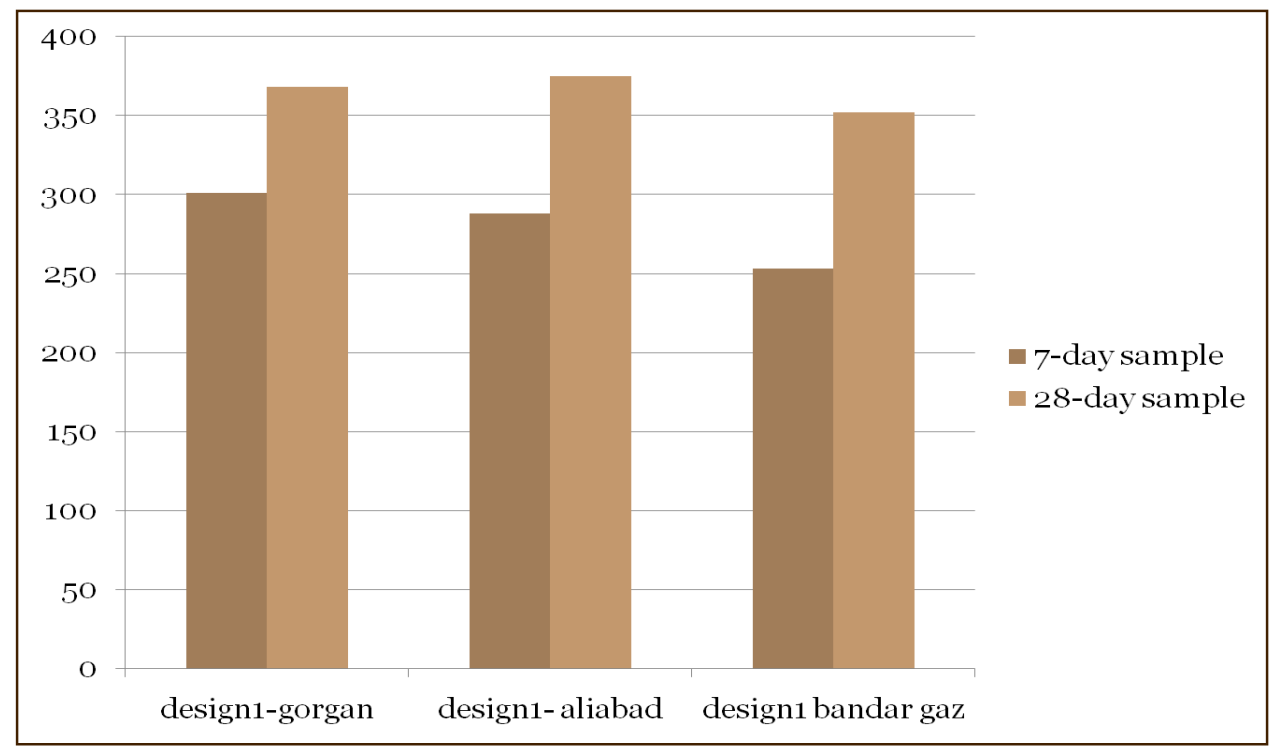

Diagram 1- compressive strength of concrete samples without admixtures

\section{CONCRETE CONTAINING ADMIXTURES}

Compressive strength test of concrete samples in grade $350 \mathrm{~kg} / \mathrm{m} 3$ containing admixtures was carried out results are represented in Diagrams 2, 3 and 4.

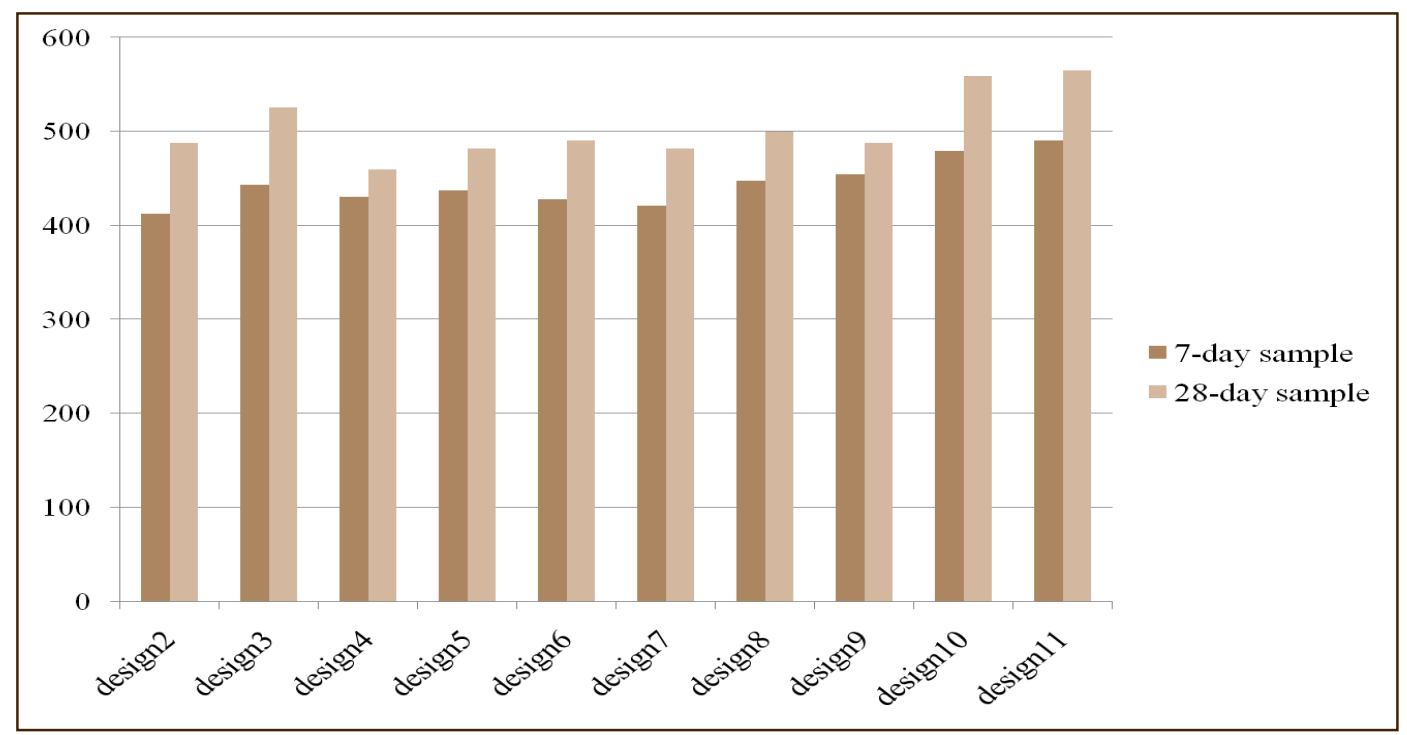

Diagram 2- compressive strength of concrete containing admixtures (Aliabad Katul)

According to Diagram related to Aliabad city, it is observed that the highest strengths related to different percentages of cloud plasticizers, followed by 28- day strength in design 3 that contained NS-MIX 3 based on naphthalene of modified sulfonate. 


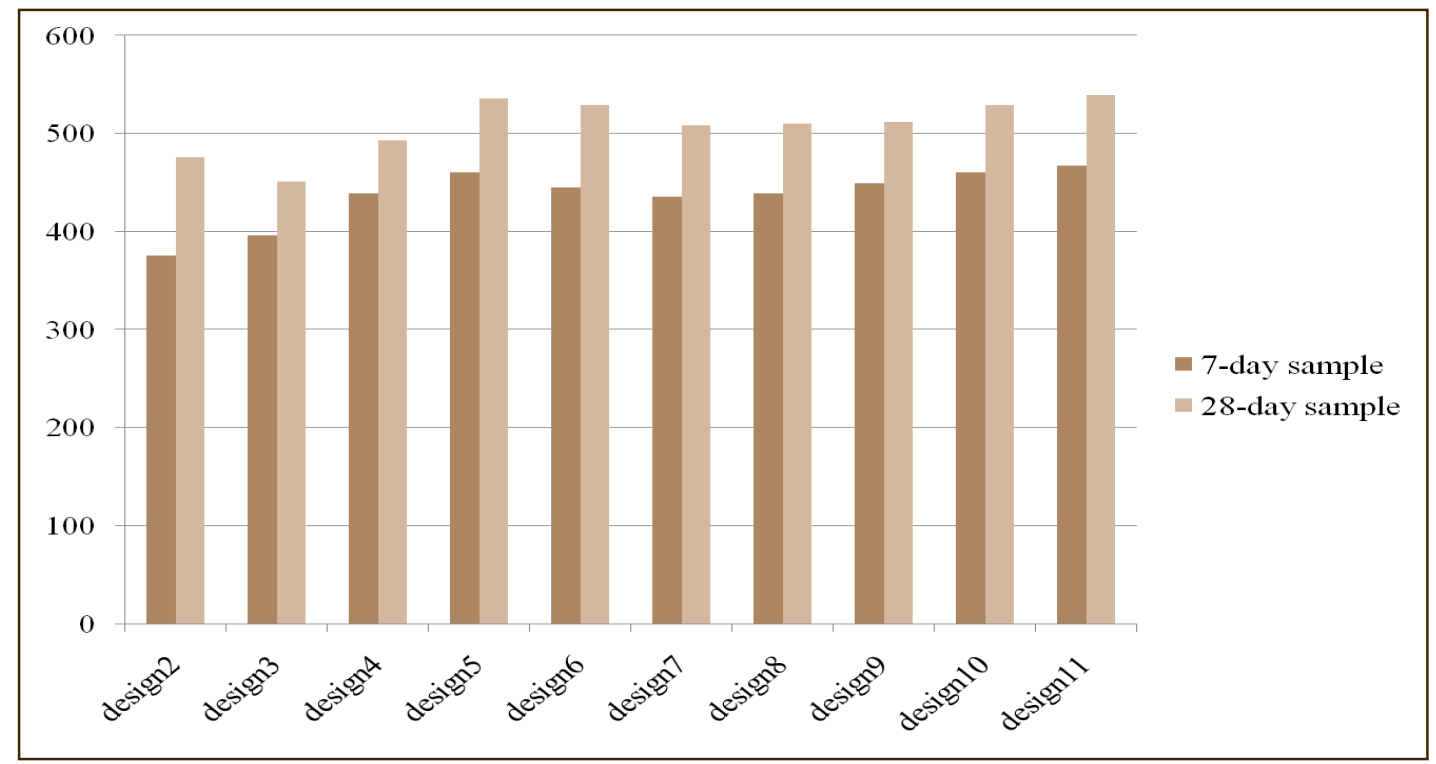

Diagram 3- compressive strength of concrete without admixtures (Gorgan)

According to Diagram related to Gorgan city, it is observed that the highest strengths related to design 11 based on cloud plasticizers, followed by 28- day strength in design 5 based on PX-MIX, and design 6 and 10 , respectively.

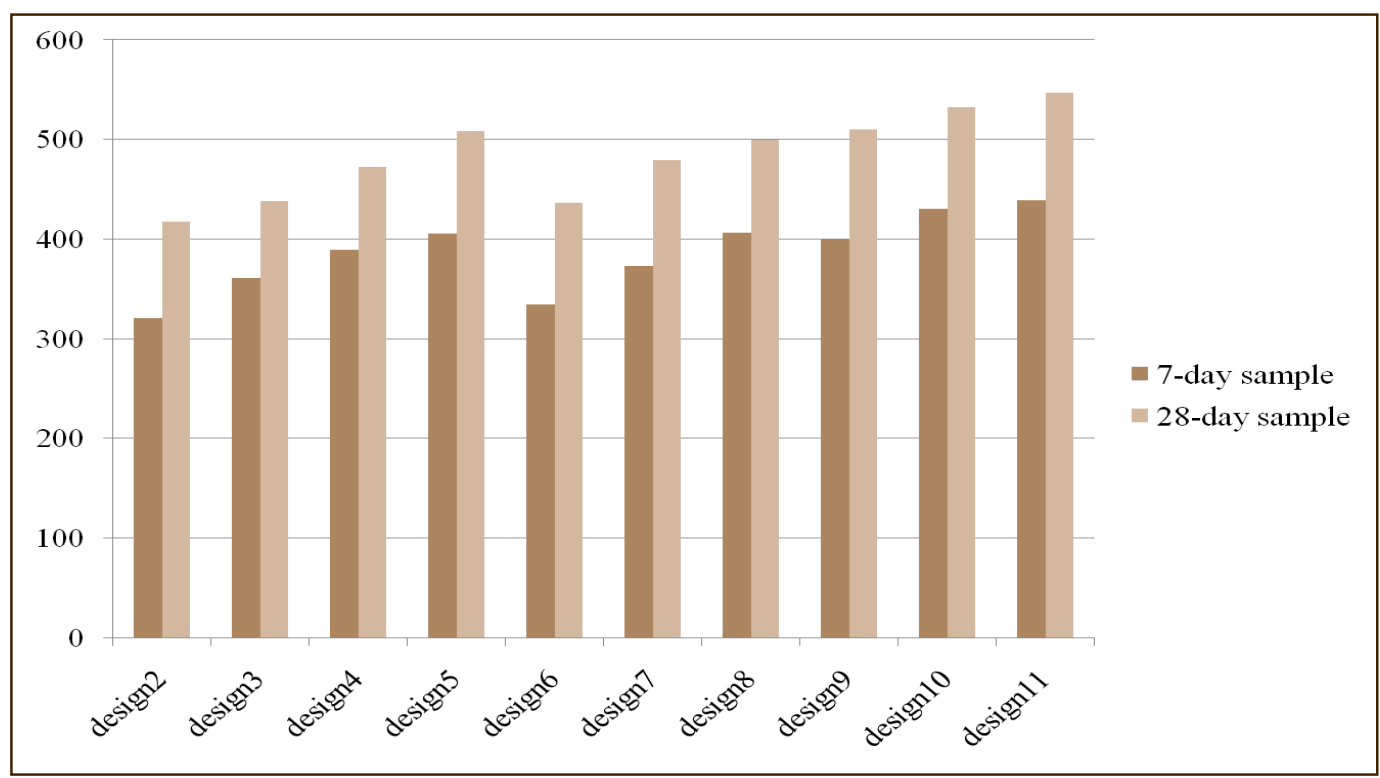

Diagram 4- compressive strength of concrete without admixtures (Bandar Gaz)

According to results presented in Diagrams above, it is seen that concrete samples strength is increasing respectively in aggregates of Aliabad, Gorgan, and Bandar Gaz. It means that aggregates of Aliabad city have higher strength compared to those in Gorgan and Bandar Gaz. In addition, aggregates of Gorgan has higher strength that those in Bandar Gaz.

\section{CONCRETE CONTAINING SUPER PLASTICIZER MATERIALS}




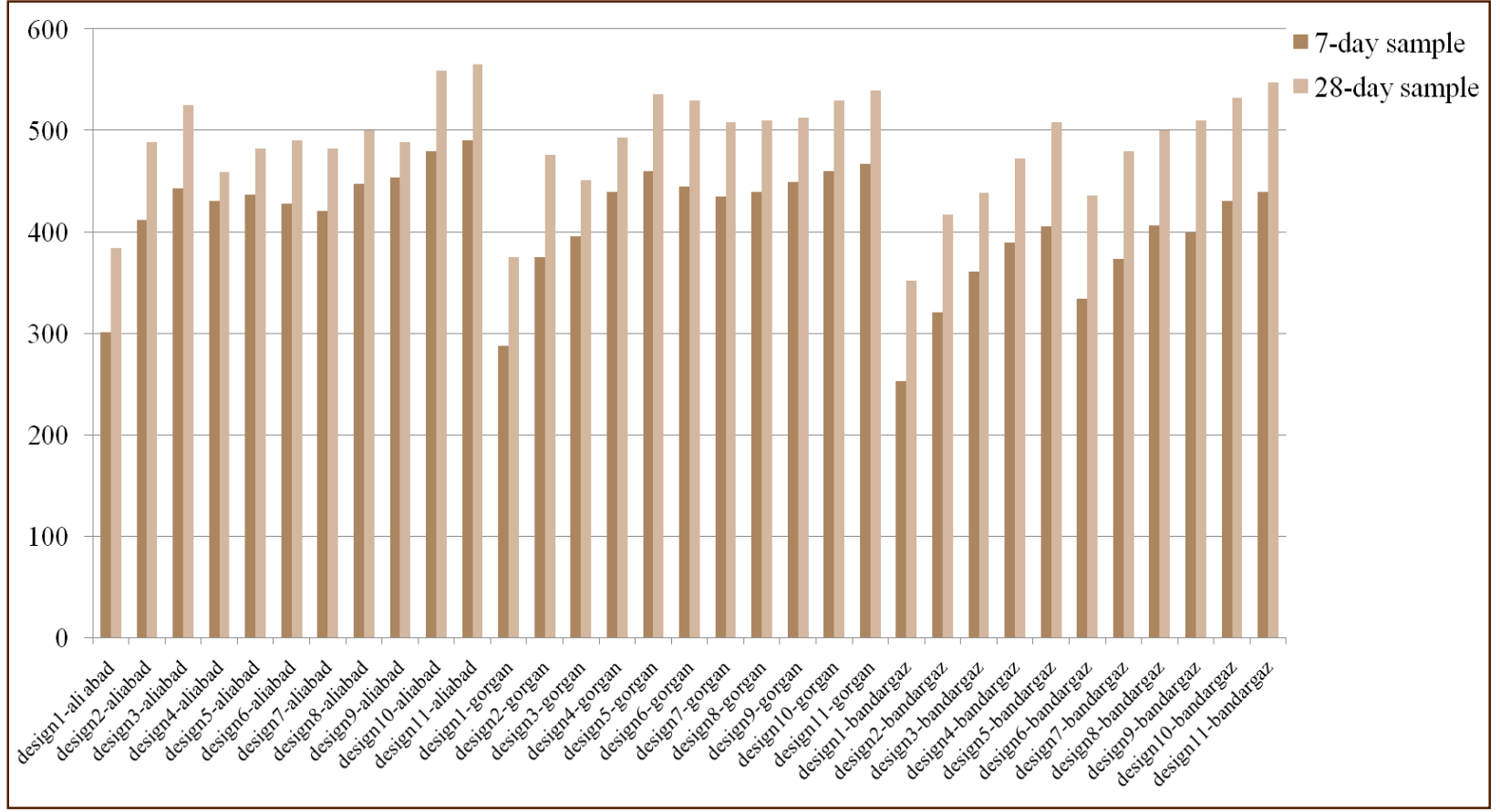

Diagram 5- concrete containing plasticizer material for three cities

In general, in Diagram, it is seen that the highest 28-day strength related to Aliabad city and in the design Carboxylate-based plasticizer. In addition, although the highest strength was observed in Aliabad followed by Gorgan and Bandar Gaz respectively in the state of without admixture, after adding admixture, the highest 28-day strength was firstly seen in Aliabad followed by Bandar Gaz and Gorgan, respectively. This suggests that with low strength of concrete constructed by Bandar Gaz aggregate, we can achieve to higher sample of concrete constructed by Gorgan aggregate.

\section{CONCLUSION}

1. Using micro-silica powder in the mix design increases compressive strength. As we increase its rate, its compressive strength increases. However, excessive use of it reduces compressive strength that this issue is important.

2. Two different percentages of each plasticizer were used in the mix design. Obtained results indicated that an increase in the rate of these plasticizers will have great impact on compressive strength and Aliabad city had the highest strength in this regard.

3. According to compressive strength test of concrete samples, it was observed that the material that had the highest impact in the concrete strength among the admixtures was Polycarboxylate ether-based cloud plasticizer with higher solid percentage. In terms of this admixture, it was indicated that compressive strength of sample concrete of Aliabad was higher than that of Gorgan and Bandar Gaz.

4. Among the designs, compressive strength of design 10 and 11 of Aliabad city containing varying percentages of PX-MIX cloud plasticizer had the highest strength. 


\section{REFERENCES}

Asadi, G., (master thesis), Azad University, Gorgan, 2015Bayat, R., 2011, types of super plasticizers, its use and impact on structures, the first Regional Conference on Civil Engineering and Architecture, Amol, Sama vocational schools of Ayatollah Amoly.

Ghodusi, P, 1997, mechanisms and te reasons for reducing the vulnerability of concrete containing microsilica, international seminar on the use of micro-silica in concrete, Building and Housing Research Center.

Karimi, K, 2011, investigating the use of using micro-silica concrete, Kermanshah Azad University, Science and Research.

Kariminia, M, Peirovi, M., 2012, to investigate the effects of different levels of carboxylate-based cloud plasticizer on the mechanical properties of structural lightweight concrete, the concrete industry's first national conference, the International Centre for concrete and advanced technology and environmental sciences Kerman, Iran

Majedi Ardakan, MH, 1995, compounds and properties of concrete super plasticizer, Building and Housing Research Center.

Rastad, MH, Yoosefzadeh, M, Nikoodel,M, 2014, The effect of gender on the compressive strength of concrete aggregate, the Eighteenth Regional Conference on Geological Society of Iran

Sadr momtazi,A ,Amooi serajari, A, 2012, Study of aggregate mines Gilan province and its effect on mechanical properties of concrete, The fourth annual National Conference of Iranian Concrete,

Taherizadeh, N, Kafi, Kh, Nikouei, M., 2013, investigating the impact of super plasticizer on durability of concrete, Islamic Azad University, Tabriz branch.

Trance, C, 2012, micro-silica using guideline, Ramezanian Pour, AA, Arabi, N, Negarande Danesh Publications. 